\title{
MAŽŲ ŪKIŲ INTERESŲ ATSTOVAVIMAS RINKOJE PER KOOPERATYVUS: POVEIKIS GAMINTOJŲ KAINAI
}

\author{
Vlada Vitunskienė ${ }^{1}$, Jolanta Droždz ${ }^{2}$, Asta Bendoraityte் $\dot{e}^{3}$, Lina Lauraitienė ${ }^{4}$ \\ ${ }^{1}$ Prof. dr. Vytauto Didžiojo universitetas. K. Donelaičio g. 58, Kaunas, Lietuva. \\ El.paštas vlada.vitunskiene@vdu.lt \\ ${ }^{2}$ Doc. dr. Vilniaus universitetas. Universiteto g. 3, Vilnius, Lietuva. \\ El.paštas jolanta.drozdz@cr.vu.lt \\ ${ }^{3}$ Dokt. Vytauto Didžiojo universitetas. K. Donelaičio g. 58, Kaunas, Lietuva. \\ El.paštas asta.bendoraityte@vdu.lt \\ ${ }^{4}$ Dokt. Vytauto Didžiojo universitetas. K. Donelaičio g. 58, Kaunas, Lietuva. \\ El.paštas lina.lauraitiene@vdu.lt
}

Pateikta 202012 02, Priimta 20201210

\begin{abstract}
Straipsnyje nagrinèjama, kokiu mastu ir kokiu būdu kooperatyvai atstovauja mažų ūkių interesams žemės ūkio produktų rinkoje. Empiriniu tyrimu siekiama nustatyti mažų ūkių įsitraukimo ị formaliają kooperaciją mastą ir kooperatyvų daromą poveikị jų parduodamų produktų kainoms Lietuvoje. Tyrimas grindžiamas konkurencinio kriterijaus, kaip kainų reguliatorius rinkoje, teorija, teigiančia, kad kooperatyvo egzistavimas oligopsoninèje rinkoje privers pelną maksimizuojančias įmones elgtis konkurencingiau. Kooperatyvui pasiūlius palankesnes kainas ūkininkams dẻl savo ịprastos praktikos teikti nariams paslaugas už savikainą, pelną maksimizuojančios perdirbimo bendrovės, siekdamos neprarasti žaliavos tiekèjų, stengiasi mokèti panašiai tiek, kiek moka kooperatyvai. Apklausos būdu nustatyta, kad Lietuvoje nedidelè mažų ūkių dalis savo pagamintą maistą ir žemės ūkio produktus parduoda per kooperatyvus ir kad tik daliai jų kooperatyvai užtikrina didesnę kainą. Atlikus ŽŪIKVC PAIS duomenų apie pirkèjų mokamą kainą už žalio pieno kilogramą analizę, gauta tokia pagrindinė išvada: Lietuvoje didžioji dalis kooperatyvų mažiems pieno gamintojams moka didesnę kainą nei penkių didžiausių pieno perdirbimo akcinių bendrovių nustatyta minimali kaina, o apie penktadalis kooperatyvų žiemos sezonu ir ne daugiau nei trečdalis kooperatyvų vasaros sezonu mokèjo didesnę kainą nei tų pačių akcinių bendrovių nustatyta maksimali kaina.
\end{abstract}

Reikšminiai žodžiai: maži ūkiai, kooperatyvai, pieno perdirbèjai, gamintojo kaina, konkurencinis kriterijus JEL kodai: L22, Q12, Q13.

\section{Ivadas}

Pasaulyje daugelis tradicinių žemės ūkio produktų rinkų keičiamos vertikalia maisto tiekimo gandinès dalyvių integracija, strateginėmis sajungomis ar sutartimis. Jos taip pat veikiamos gamintojų ,jungtinès veiklos“ organizacijų, tokių kaip rinkodaros (pardavimo) kooperatyvai, gamintojų organizacijos ir pan. Kooperatyvai yra atsakas ị silpną pavienių ūkių derybinę galią oligopsoninèje rinkoje, kurioje nedaug pirkejjų (Vitunskienė, 2019). Nourse'as (1922, cituota iš Myers, Sexton, Tomek, 2010, p. 377) buvo vienas iš XX a. pradžios autorių, nuogąstavusių dėl galios disbalanso tarp ūkininkų ir žemès ūkio produkciją iš jų superkančių firmų. Rinkos galios disbalansui panaikinti skatino ūkininkus formuoti kooperatyvus (ibid.).

Rinkoje kooperatyvai gali padèti gamintojams įvairiais būdais, iš kurių du yra būdingi jų veiklai rinkoje - tai kompensacinè galia ir konkurencinis kriterijus, t. y. kainų rinkos reguliatorius (KispálVitai, Regnard, Kövesi, Guillotte, 2019). Kooperatyvai ar kitos gamintojų organizacijos mažiems ūkiams suteikia galimybę ịsitraukti ị šiuolaikines žemès ūkio vertės grandines, juolab, kad tradicinèse rinkose dominuoja stambūs ūkiai (Zakić, Vukotić, Cvijanović, 2014). Maži ūkiai, vykdydami individualią veiklą, turi mažai galimybių konkuruoti tradicinèje rinkoje, todèl viena iš galimybių yra vietos maisto sistemos, o jų kūrimo būdas - ūkininkų kooperacija.

Copyright (C) 2020. Published by Vytautas Magnus University. This is an open access article distributed under the terms of the Creative Commons Attribution Non-Commercial 4.0 (CC BY-NC 4.0) license, which permits unrestricted use, distribution, and reproduction in any medium provided the original author and source are credited. The material cannot be used for commercial purposes. 
Kooperacija itin svarbi mažiems ūkiams, kurie ir yra vietinių maisto sistemų puoselètojai. Kooperacija skatina vystyti bendrą infrastruktūrą (techniką, logistiką ir transportą), vieningus maisto gamybos ir perdirbimo metodus bei bendrą žemès ūkio patirtị. Taip mažinamos išlaidos ir darbo jègos sąnaudos (Lutz, Smetschka, Grima, 2017). Kooperacija ne tik prisideda prie gamybos kaštų mažinimo, bet ir padeda organizuoti tam tikras rinkas (Souza, Fornazier, Delgrossi, 2020). Gamintojų organizacijos padeda sumažinti mažų gamintojų kliūtis patekti ị rinką (Herbel, Haddad, 2012).

Vakarų ir Skandinavijos šalių patirtys įrodo, jog per kooperatyvą veikiantys maži ir vidutiniai ūkiai padidina savo derybines galias rinkoje, užsitikrina didesnes pajamas ir tampa konkurencingesni, sumažina gamybos ir logistikos kaštus (ŽŪM, 2020). O Lietuvoje, kaip rodo Žemès ūkio rūmų duomenys, kooperacija tarp ūkininkų nèra paplitusi - tik apie 12 proc. šalies ūkininkų yra įsitraukę i kooperatyvus (Kiselienè, 2019). Agarwal ir Dorin (2019), atlikę grupinio ūkininkavimo tyrimą Prancūzijoje, nustatè priežastis, kodèl vieni regionai linkę labiau kooperuotis nei kiti: 1) kooperacija labiau paplitusi regionuose, kuriuose yra maža ekonominè nelygybė ir vyrauja maži arba vidutinio dydžio ūkiai; 2) kooperuotis labiau linkę darbo jègai imlia žemès ūkio veikla užsiimantys ūkiai, t. y. gyvulių augintojai labiau linkę kooperuotis nei grūdų augintojai; 3) įtakos turi demografiniai veiksniai, pavyzdžiui, žemès ūkio išsilavinimas, ir pan. Galima pridurti, kad tam ịtakos turi žemès ūkio vystymosi istorinès sąlygos regionuose ar šalyse. Priešingai nei Vakarų šalyse, kur ūkių kooperatyvai plačiai paplitę ir sẻkmingai veikia pastarajị šimtmetį, žemès ūkio kooperatyvų raida Lietuvoje buvo netolygi. Antrajame ir trečiajame dešimtmetyje išplètotą klasikiniais bendradarbiavimo principais paremtą ūkių kooperaciją sunaikino sovietizacija. Pusę šimtmečio veikę kooperatyvais laikyti kolūkiai dar ir šiandien yra išlikę kaip naudos neteikiantis antikooperacijos vaizdinys, atbaidantis individualiai ūkininkaujančiuosius nuo jungimosi ị kooperatyvus. Po pokomunistinès agrarinès reformos kooperacija Lietuvos žemès ūkyje taip ir neišsiplètojo, praejjus ketvirčiui amžiaus vis dar yra labai silpna.

Tyrimai rodo, kad kolektyviniai veiksmai suteikia ūkininkams galimybę neutralizuoti pirkejju rinkos galią (Myers, Sexton, Tomek, 2010). Teoriniai modeliai ir empiriniai duomenys rodo, kad didelè kooperatyvų rinkos dalis gali priversti $\mathfrak{i}$ investuotojus orientuotas perdirbimo įmones mokèti didesnes kainas ūkininkams. Lygiai taip pat kooperatyvai gali priversti įmones sumažinti kainų svyravimus (Müller, Hanisch, Malvido, Rommel, Sagebiel, 2018). Nors yra daug teorinių darbų apie teigiamą kooperatyvų poveiki rinkos galiai, tačiau, kaip pastebi Grashuis (2020), taikomujų tyrimų yra gana mažai. Lietuvoje yra mažai žinių ne tik apie ūkių (taip pat ir mažų) įsitraukimo ị kooperaciją mastą, bet ir kokią naudą kooperatyvai jiems teikia. Norėdamos ištirti, koks yra kooperatyvų poveikis mažų ūkių parduodamo pieno kainai Lietuvos rinkoje, remiamès 2019 m. atliktos mažų šeimos ūkių apklausos duomenimis apie maisto ar žemès ūkio produktų pardavimo sutartis, pagal kurias ūkiai gauna didesnes kainas, ir ŽŪIKVC PAIS skelbiama informacija apie pirkëjų mokamą kainą už žalio pieno kilogramą. Beje, Lietuvos praktikoje ir statistikoje, kalbant apie kainą, mokamą žemès ūkio gamintojams už iš jų supirktus produktus, plačiai vartojamas ,supirkimo kainos“ terminas, kuris atitinka „gamintojų kainos“ terminą, vartojamą užsienio mokslinėje literatūroje ir statistikoje. Šiame straipsnyje abu terminai laikomi sinonimais ir vartojamas ,gamintojų kainos“" terminas. tojų kainai.

Tyrimo objektas - mažų ūkių interesų atstovavimas rinkoje per kooperatyvų poveikį gamin-

Tyrimo tikslas - nustatyti mažų ūkių ịsitraukimo ị formaliąją kooperaciją mastą ir kooperatyvų daromą poveiki jų parduodamų produktų kainoms Lietuvoje.

Tyrimo metodai - dedukcija, sintezè, apklausa, palyginamoji analizè, duomenų statistinè analizè.

\section{Tyrimo koncepcija, metodika ir apribojimai}

\section{Kooperatyvu poveikio gamintoju kainai teorinis pagrindas}

Kooperatyvai viešosios politikos požiūriu yra laikomi konkurenciją skatinančiomis rinkos priemonėmis (Torgerson, Reynolds, Gray, 1998), nes jie paprastai suvokiami kaip konkurencinès jègos, kurios pagerina netobulų rinkų veiklą ir padidina bendrą ekonominę gerovę (Hoffman, Royer, 1997). Oligopsoninèje rinkoje nedaug pirkèjų susiduria su daugybe gamintojų, todèl pirkèjų galia 
rinkoje yra žymiai didesnė nei gamintojų (Kispál-Vitai, Regnard, Kövesi, Guillotte, 2019; Vitunskienė, 2019). Kooperatyvai gali padèti gamintojams ịvairiais būdais, iš kurių du yra būdingi jų veiksmams rinkoje, t. y. kompensacinè galia ir konkurencinis kriterijus, pasireiškiantis kaip kainų reguliatorius rinkoje (Kispál-Vitai, Regnard, Kövesi, Guillotte, 2019).

Konkurencinio kriterijaus teorija (competitive yardstick) paaiškina, kaip oliogopsoninèje rinkoje, kurioje vyrauja pelną maksimizuojančios perdirbimo bendrovès, kooperatyvai užtikrina aukštesnes žemès ūkio produktų kainas regione (Müller, Hanisch, Malvido, Rommel, Sagebiel, 2018). „Konkurencinio kriterijaus“ koncepcija teigia, kad kooperatyvo egzistavimas rinkoje priverčia pelną maksimizuojančias įmones elgtis konkurencingiau. Konkurencinio kriterijaus logika yra tokia: kai kooperatyvas pasiūlo ūkininkams palankesnes kainas dèl savo klasikinès praktikos teikti nariams paslaugas už savikainą, tuomet pelną maksimizuojančios perdirbimo bendrovès stengsis prilygti kooperatyvo mokamai kainai, kad neprarastų žaliavos tiekejjų. Tuomet rinka judès konkurencinès pusiausvyros link (Hoffman, Royer, 1997). Panašių praktinių pavyzdžių pateikia dabartinė Lietuvos žalio pieno rinka. Interviu su pienininkystės šakos verslo asociacijų atstovais (Vituskienė, Droždz, Lauraitienè, Bendoraitytè, 2020) atskleidè, kad palaipsniui didejjanti kooperatyvų dalis žalio pieno rinkoje keičia joje vyraujančių pieno perdirbimo bendrovių konkurencinę elgseną - siekdamos iš kooperatyvų pervilioti pieno gamintojus, jos sutartyje pasiūlo 1-2 centais didesnę nei kooperatyvo nustatyta pieno kilogramo kainą.

Remdamosi konkurencinio kriterijaus teorija, šiame straipsnyje siekiame empiriškai ištirti kooperatyvų galimą poveikị jų atstovaujamų smulkių gamintojų parduodamų žemės ūkio produktų kainoms rinkoje. Žemès ūkio kooperatyvai klasifikuojami ị tris plačias kategorijas pagal jų pagrindinę veiklą: rinkodaros (kurie gali derètis dèl geresnių kainų, tvarkyti, perdirbti ar gaminti ir parduoti žemès ūkio produktus); tiekimo (kurie gali pirkti, gaminti, perdirbti ar suformuoti bei paskirstyti žaliavas, tokias kaip sèklos, trąšos, pašarai, chemikalai, naftos produktai, ūkio įranga, metalo gaminiai ir statybinès medžiagos) ir paslaugų (kurie teikia transportavimo, sandèliavimo, dirbtinio apvaisinimo, kreditavimo, draudimo ir kt. paslaugas) (Ortmann, King, 2007). Šiuo tyrimu siekiame nustatyti rinkodaros kooperatyvų poveikį mažų ūkių žemès ūkio produktų pardavimo rinkoje kainoms. Kitų minètų kategorijų žemės ūkio kooperatyvų efektas mažiems ūkiams nenagrinėjamas.

\section{Tyrimo kintamieji ir duomenu šaltiniai}

Pirma, remiantis 2019 m. Lietuvos mažų šeimos ūkių darnumotyrimo kiekybinès apklausos duomenimis, šiame straipsnyje tiriama:

- mažų ūkių ịsitraukimo ị kooperatyvų veiklą ir pagamintų maisto ir (ar) žemès ūkio produktų pardavimo per kooperatyvus aprèptys, t. y. kokia jų dalis dalyvauja žemės ūkio kooperatyvo veikloje ir kokia jų dalis parduoda savo pagamintą maistą ir žemès ūkio produktus per kooperatyvus;

- galimas kooperatyvų poveikis šių ūkių parduodamų maisto ir žemės ūkio produktų kainoms rinkoje, t. y. kokia dalis ūkių užsitikrina didesnę kainą, savo pagamintą maistą ir žemès ūkio produktus parduodami per kooperatyvus.

Tyrimui duomenys paimti iš 1002 mažų šeimos ūkių apklausos, atliktos 2019 m. pagal FAMFAR tarptautini projektą „Mažų šeimos ūkių vaidmuo siekiant tvaraus žemès ūkio ir maisto produktų sektoriaus vystymosi Vidurio ir Rytų Europos šalyse“ (2019-2021), finansuojamą Lenkijos akademinių mainų nacionalinès agentūros (NAWA) (Vitunskienè, Droždz, Bendoraitytė, 2020). Pagal fizinị ūkio dydị apklausoje dalyvavę ūkiai pasiskirstė taip: 14,3 proc. sudare „trihektarininkai“ (iki 3 ha žemès), 39,5 proc. - 3-10 ha, o likusiają dali (46,2 proc.) - 10-20 ha ūkiai. Pagal ịsitraukimo i rinką lygị, mažiau nei 50 proc. savo pagamintų maistui ar perdirbimui skirtų produktų parduota 28,5 proc. ūkių, o daugiau kaip 50 proc. - 71,5 proc.

Veikiančių kooperatyvų išplitimui ir jų struktūrinėms ypatybėms bei ūkininkų ịsitraukimo ị juos aprépčiai nustatyti kaip papildoma informacija naudojami LR žemès ūkio rūmų atliktos Lietuvos žemès ūkio kooperatyvų ir kooperatinių bendrovių $2019 \mathrm{~m}$. apklausos duomenys $(\mathrm{N}=102)$. .

Antra, remiantis ŽŪIKVC PAIS skelbiama informacija apie individualių pirkejjų pateiktą vidutinę faktinę bazinių rodiklių žalio pieno kainą (EUR/kg), atlikta kooperatyvų ir žalio pieno rinkoje 
vyraujančių penkių didžiausių pieną perdirbančių akcinių bendrovių (Top5 AB ir UAB) palyginamoji analizè, siekiant nustatyti:

- kooperatyvų ir Top5 AB ir UAB mažiems pieno ūkiams mokamų žalio pieno kainų lygị ir skirtumus pagal per vieną dieną iš jų superkamo pieno kiekio grupes (iki $100 \mathrm{~kg}, 100-200$ $\mathrm{kg}, 200-300 \mathrm{~kg}$ per dieną). Individualaus supirkejjo mokamos kainos lygis (proc.) apskaičiuotas kaip procentinis santykis tarp jo kainos ir vidutinès visų supirkejjų mokamos kainos toje pačioje superkamo pieno kiekio grupejje;

- kokia kooperatyvų dalis mažiems pieno ūkiams moka didesnes nei Top5 AB ir UAB minimali ir maksimali žalio pieno kaina pagal per vieną dieną iš individualaus gamintojo superkamo pieno kiekio grupes (iki $100 \mathrm{~kg}, 100-200 \mathrm{~kg}, 200-300 \mathrm{~kg}$ per diena);

Analizè atlikta remiantis ŽŪIKVC PAIS informacija apie penkių didžiausių pieną perdirbančių akcinių bendrovių (Top5: AB „Žemaitijos pienas“, AB „Pieno žvaigždès“, UAB „Marijampolès pieno konservai“, AB „Rokiškio sūris“ ir AB ,Vilkyškių pieninė“) ir 27 kooperatyvų 2018 m. liepos mèn. bei 30 kooperatyvų $2018 \mathrm{~m}$. gruodžio mèn. pateiktą vidutinę faktinę bazinių rodiklių pieno kainą superkant pieną iš pieno gamintojų (EUR/kg) pagal per vieną dieną iš gamintojų superkamo pieno kiekio grupes. Analizuoti dvejopi informacijos srautai apie supirkèjų mokètas žalio pieno kainas: 1) vasaros ir žiemos sezonų, atitinkamai liepos ir gruodžio mėnesių kainas; 2) kainas, priklausančias nuo žalio pieno pristatymo būdo, t. y. kai pienas iš ūkio pristatomas į supirkimo punktą (SP) ir kai paimamas tiesiogiai iš ūkio (TÜ).

\section{Tyrimo rezultatai}

Mažu ūkiu isitraukimo ị kooperatyvu veiklą mastas

LR žemès ūkio rūmų 2019 m. tyrimo duomenimis, Lietuvoje 2019 m. pradžioje buvo ịregistruoti 323 žemės ūkio veikla užsiimantys kooperatiniai vienetai. Tačiau tyrimo metu paaiškejjo, kad 147 kooperatyvų veikla sustabdyta, nutraukta arba jie yra likviduojami. Dauguma žemès ūkio kooperatyvų yra palyginti maži. Pavyzdžiui, 102 kooperatyvų (tai 58 proc. tuo metu veikusių kooperatyvų) apklausos rezultatai rodo, kad du trečdaliai kooperatyvų turi ne daugiau kaip po dešimt narių, o per šimtą narių - vos 8 proc. kooperatyvų. Pusès kooperatyvų veikla susijusi su augalininkyste ir gyvulininkyste (1 pav.).

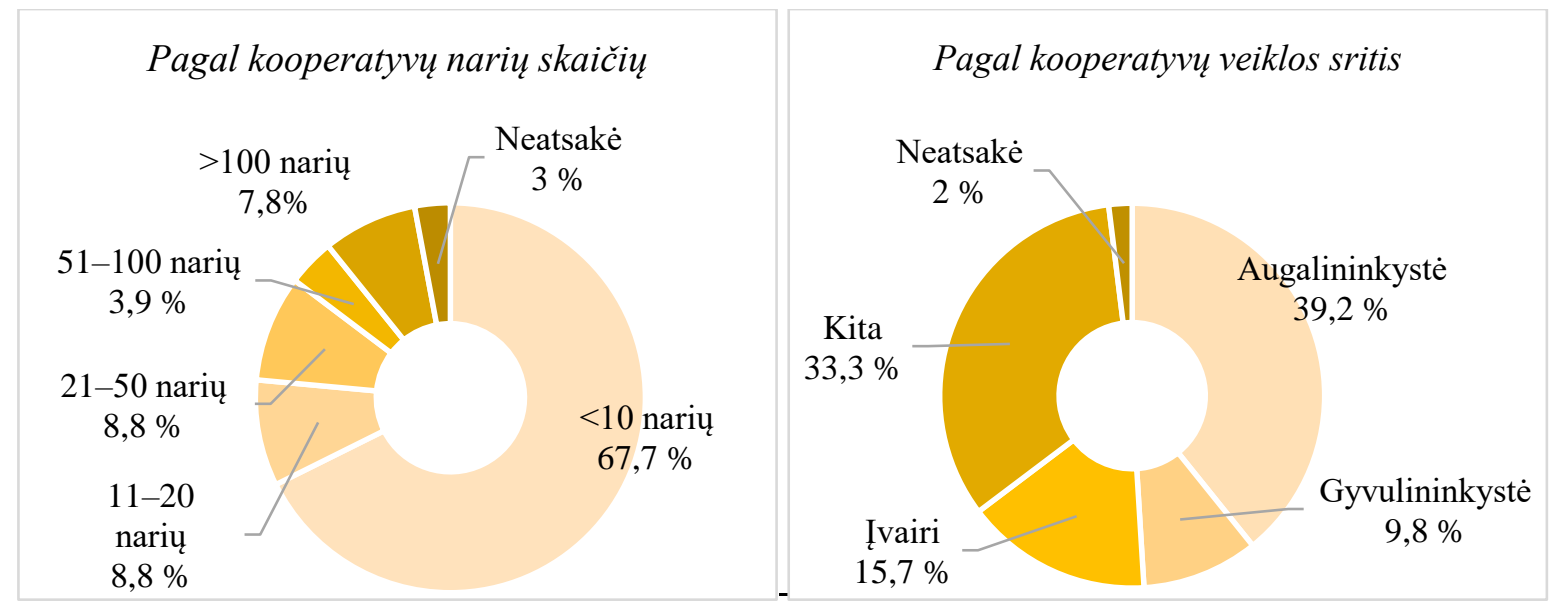

1 pav. Lietuvos žemès ūkio kooperatyvų struktūra pagal narių skaičių ir veiklos sritis (pagal 58 proc. 2019 m. veikusių kooperatyvų apklausą)

Šaltinis: parengta autorių pagal LR Ž ŪR kooperatyvų apklausos duomenis 2019 m. (N=102) 
Kaip minèta, tik šiek tiek daugiau kaip dešimtadalis Lietuvos ūkių yra ịsitraukę i formalių kooperatyvų veiklą. Vadinasi, nedidelès mažų ūkių ${ }^{1}$ dalies interesams rinkoje atstovauja kooperatyvai. 2019 m. Lietuvoje atliktos per tūkstančio mažų šeimos ūkių apklausos rezultatai (2 pav.) rodo, kad 8 proc. jų dalyvauja bei planuoja toliau tęsti narystę kooperatyve ir dar 8 proc. planuoja įsitraukti i kooperatyvo veiklą. Tačiau tik pusè (t. y. 4 ir 8 proc.) kooperatyvo veikloje dalyvaujančių mažų šeimos ūkių savo pagamintus maisto bei žemès ūkio produktus rinkoje parduoda per kooperatyvus (2 pav.).

Net 57 proc. nedidelių šeimos ūkių nedalyvauja kooperatyvų veikloje ir neketina tapti jų nariais, o 22 proc. apskritai neturi nuomonès šiuo klausimu (2 pav.). Tyrimas rodo, kad labai maži „trihektarininkų“ ūkiai (taip praminti pagal minètą Seimo 1990 m. nutarimą „Dėl kaimo gyventojų sodybinių sklypų išplètimo iki 2-3 hektarų“) nèra ịsitraukę i jokių formalių kooperatyvų veiklą. Tik daugiau kaip dešimtadalis jų planuoja tai padaryti. Kooperatyve dalyvauja bei planuoja i ji ịsitraukti beveik šeštadalis 3-10 ha žemès dirbančių ūkių ir beveik penktadalis nuo 10 iki 20 ha žemès dirbančių ūkių.

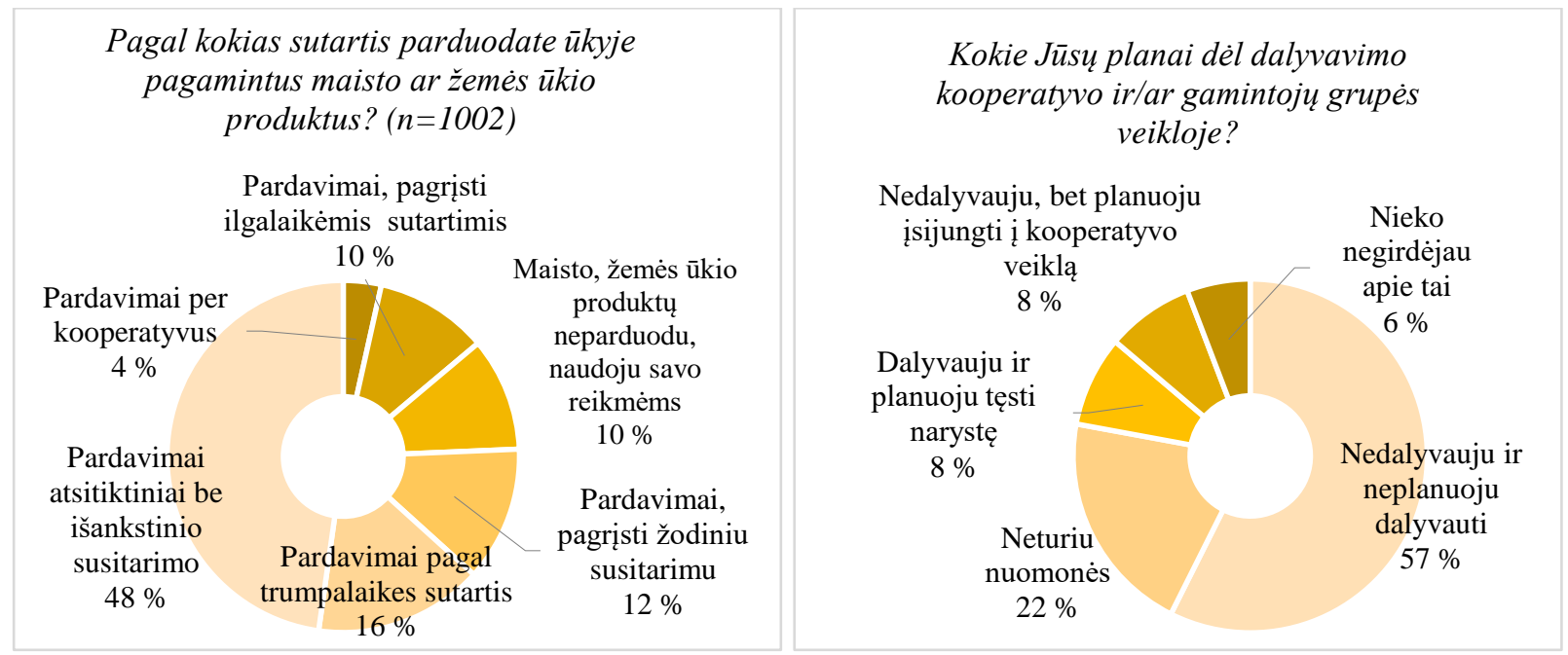

\section{2 pav. Mažų šeimos ūkių maisto ir žemès ūkio produktų padavimo būdai ir įsitraukimas į ko- operatyvų veiklą Lietuvoje}

Šaltinis: parengta autorių pagal 2019 m. mažų šeimos ūkių apklausos duomenis (N=1002)

Vykdant RETHINK projektą atlikta ūkininkų ir žemès ūkio vadybininkų apklausa (Atkočiūnienè, Aleksandravičius, Dautartè, Vitunskienè, Zemeckis, 2016) atskleidè, kad pagrindinès nenoro kooperuotis ir keistis priežastys yra jų individualumas, pasitikejjimo kolektyviniais (kooperuotais) veiksmais ir naujomis idejjomis stoka, vidinè konkurencija ir negebejjimas susitarti. Apklausos duomenimis, tiek ūkininkai, tiek korporuotų žemės ūkio įmonių vadybininkai kooperacijos nelaiko pirmo

\footnotetext{
${ }^{1}$ Žemès ūkio struktūros tyrimo 2016 m. duomenimis, pusè Lietuvos ūkių (75 tūkst.) turèjo mažiau nei 5 ha žemės ir dar penktadalis ūkių (beveik 33 tūkst.) naudojo nuo 5 iki 10 ha. Tokị didelị labai mažų ūkių skaičių Lietuvoje nulèmė istoriniai veiksniai, iš esmès du Lietuvos Seimo sprendimai. Pirma, tai - nutarimas (1990) „Dèl kaimo gyventojų sodybinių sklypų išplètimo iki 2-3 hektarų“. Tokiu sprendimu pirmiausia buvo siekta socialinio tikslo - sustiprinti kaimo gyventojus. Sovietmečiu tokie ūkiai buvo vadinami „kaimo gyventojų pagalbiniais ūkiais“, šeimos poreikiams buvo leidžiama naudoti iki 60 arų žemès. Lietuvoje 1990 m. pradžioje buvo 464 tūkst. gyventojų sodybinių ūkių, kurių vidutinis dydis buvo 0,64 hektaro, ir sudare 6,4 proc. šalies žemès ūkio paskirties žemès ploto. Iki $1994 \mathrm{~m}$. pradžios šių ūkių sumažèjo iki 404 tūkst., jų vidutinis dydis padidejjo iki 2,1 hektaro, ir tai sudarè 26,2 proc. šalies žemès ūkio paskirties žemès. Daug jų išliko iki šių dienų ir yra natūriniai arba pusiau natūriniai. Antra, tai - Lietuvos Seimo sprendimas (1991) „Dèl žemės nuosavybės teisių atstatymo ir žemès grąžinimo buvusiems savininkams iki 1940-07-22“. Atkūrus privačios žemės nuosavybės teisę savininkams bei jų teisès paveldètojams buvo sudarytos teisinès prielaidos smulkiems šeimos ūkiams susikurti. 1994 m. pradžioje Lietuvoje tokių šeimos ūkių buvo 112 tūkst., vidutinis dydis siekė 8,8 ha, ir tai sudarė 27 proc. šalies žemès ūkio paskirties žemès (Vitunskienè, 2001, p. 27).
} 
būtinumo klausimu, jiems, anot ekspertų, kasdieniniai darbai ūkyje yra didesnè vertybė nei pokyčiai bendradarbiavimo srityje. Be to, jie mano, kad stokoja laiko bendradarbiavimo veiksmams dèl didelio darbo krūvio. Žmonių tarpusavio nepasitikejjimą, nenorą keisti savo veiklos ịpročius ir skirti laiko kooperatyvo veiklai kaip pagrindinius barjerus ūkių kooperacijos vystymuisi Lietuvoje nustate ir ankstesni tyrimai (Pareigienè, Ribašauskienè, 2008; Kuliešis, Pareigienė, 2010). Taip pat nustatyta, kad ūkininkų kooperacija yra ribojama jų polinkiu konkuruoti ir negebejjimu identifikuoti bendru veiksmų naudos (Melnikienè, Vidickienè, 2019). Visa tai rodo, kad ūkininkaujančiujų nusiteikimo prieš kooperaciją pamatinès priežastys nesikeičia ilgą laiką. Kad naujam bendradarbiavimui užmegzti reikia daug laiko, teigia ir užsienio ūkininkai, taip pat manantys, kad gali būti sudètinga organizuoti kooperatinėse įmonėse vykstančius darbo procesus ir komunikaciją (Lutz, Smetschka, Grima, 2017). Be to, šiuolaikinèse žaliavinių žemės ūkio produktų rinkose mainus valdo stabilūs sutartiniai santykiai tarp ūkių ir supirkèjų (Crespi, Saitone, Sexton, 2012), kurie stabdo ūkių jungimąsi ị kooperatyvus Lietuvoje.

Menkam mažų šeimos ūkių įsitraukimui ị formalių kooperatyvų veiklą ịtaką daro neformali tarpusavio pagalba. Kaip nurodo Lutz, Smetschka ir Grima (2017), šalyse, kuriose yra daug nedideliu šeimos ūkių, labai ịprastas yra neformalus jų bendradarbiavimas, kai ūkininkai dalijasi technika ir žemès ūkio gamybos patirtimi bei padeda vieni kitiems esant dideliam darbo krūviui. Autoriai pabrěžia, kad taip pat galima rasti ir neformalių kooperatyvų, kurie dažnai yra elementarūs susitarimai, kai vienas ūkininkas kitų ūkininkų produktus pasiima ị rinką ir parduoda be papildomo mokesčio. Tokios kooperacijos paskata yra didesnis kiekvieno ūkininko produktų patrauklumas rinkoje, kai jie parduodami šalia platesnio kitų aukštos kokybės produktų asortimento. Toks neformalus bendradarbiavimas yra panašus į abipusę pagalbą, kuri dažnai būna tarp giminaičių ar kaimynų ir yra grindžiamas pasitikejjimu ir nuolatiniu asmeninių santykių puoselejjimu. Tai Treinys (1990) taikliai pavadino „talka“. Neformalų tarpusavio bendradarbiavimą Kuliešis ir Pareigienė (2010) nustatė kaip vieną iš pagrindinių ūkininkų nesikooperavimo priežasčių Lietuvoje. Galima manyti, kad tai ypač būdinga smulkiems ūkininkams.

\section{Kooperatyvu poveikis gamintoju kainoms mažuose ūkiuose}

3 paveiksle pateikti duomenys rodo, pagal kokias maisto ar žemės ūkio produktų pardavimo sutartis maži šeimos ūkiai gauna didesnes kainas. 180 iš tyrime dalyvavusių 1002 ūkių nurodè, kad didesnę kainą jie gauna pagal trejopus pardavimo būdus. 18 proc. (arba 35 iš 180 ūkių) nurodè, kad didesnę kainą gauna parduodami per kooperatyvus. Kad savo pagamintus maisto ar žemès ūkio produktus parduoda per kooperatyvus, iš viso nurodè 42 (arba 4,2 proc.) apklausoje dalyvavusių ūkių. Taigi daugiau kaip keturiems penktadaliams ūkių dalyvavimas kooperatyvo veikloje užtikrino aukštesnę kainą.

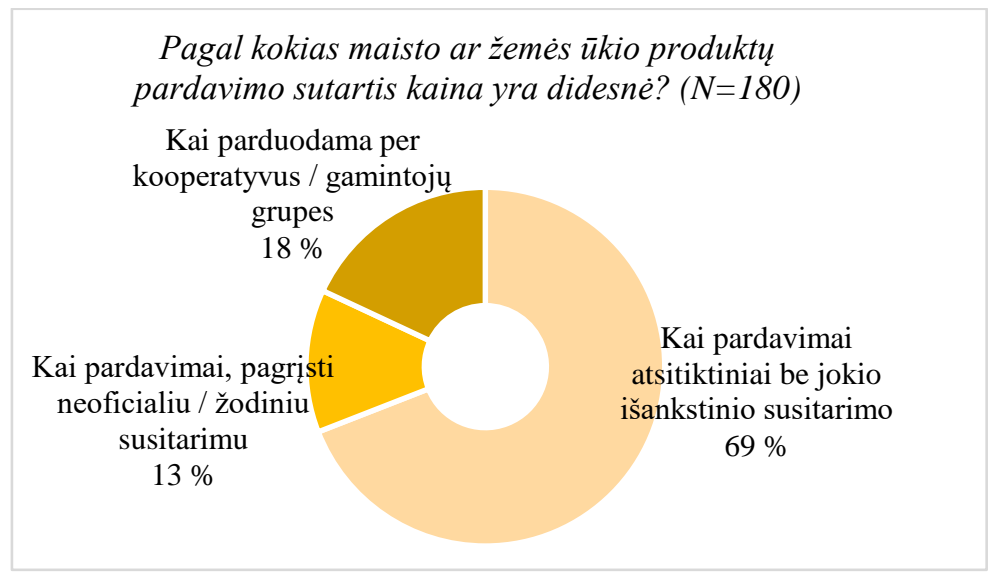

3 pav. Kooperatyvų poveikis mažų šeimos ūkių maisto ir žemės ūkio produktų kainoms Lietuvoje Šaltinis: parengta autorių pagal mažų šeimos ūkių apklausos 2019 m. duomenis $(\mathrm{N}=1002)$ 
4 paveiksle pateikti duomenys apie kooperatyvų ir penkių lyderiaujančių pieno perdirbimo įmonių (Top5) mokamas žalio pieno kainas pagal per vieną dieną iš gamintojų superkamo pieno kiekio grupes rodo, kad maži ūkiai gali gauti didesnę kainą žemės ūkio produktus perdirbimui parduodami per kooperatyvus.

Vasaros sezono kainos (2018 m. liepos mèn.)

SP - žalias pienas, pristatomas $\grave{i}$ supirkimo punkta

$T \bar{U}$ - žalias pienas, paimamas tiesiogiai iš $\bar{u} k i o$

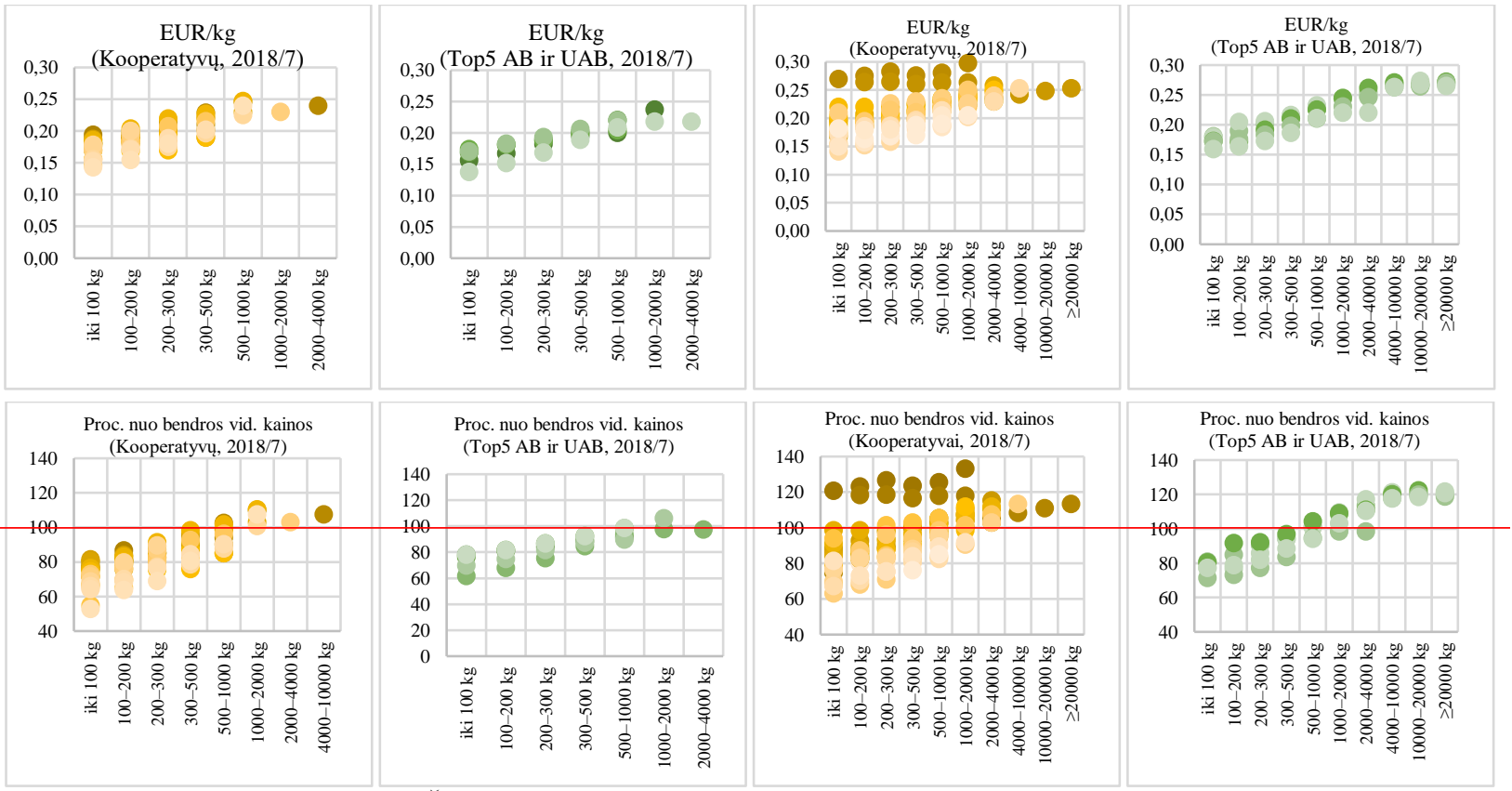

Žiemos sezono kainos (2018 m. gruodžio mèn.)

$S P$-žalias pienas, pristatomas i supirkimo punkta $\quad T \bar{U}$-žalias pienas, paimamas tiesiogiai iš ükio

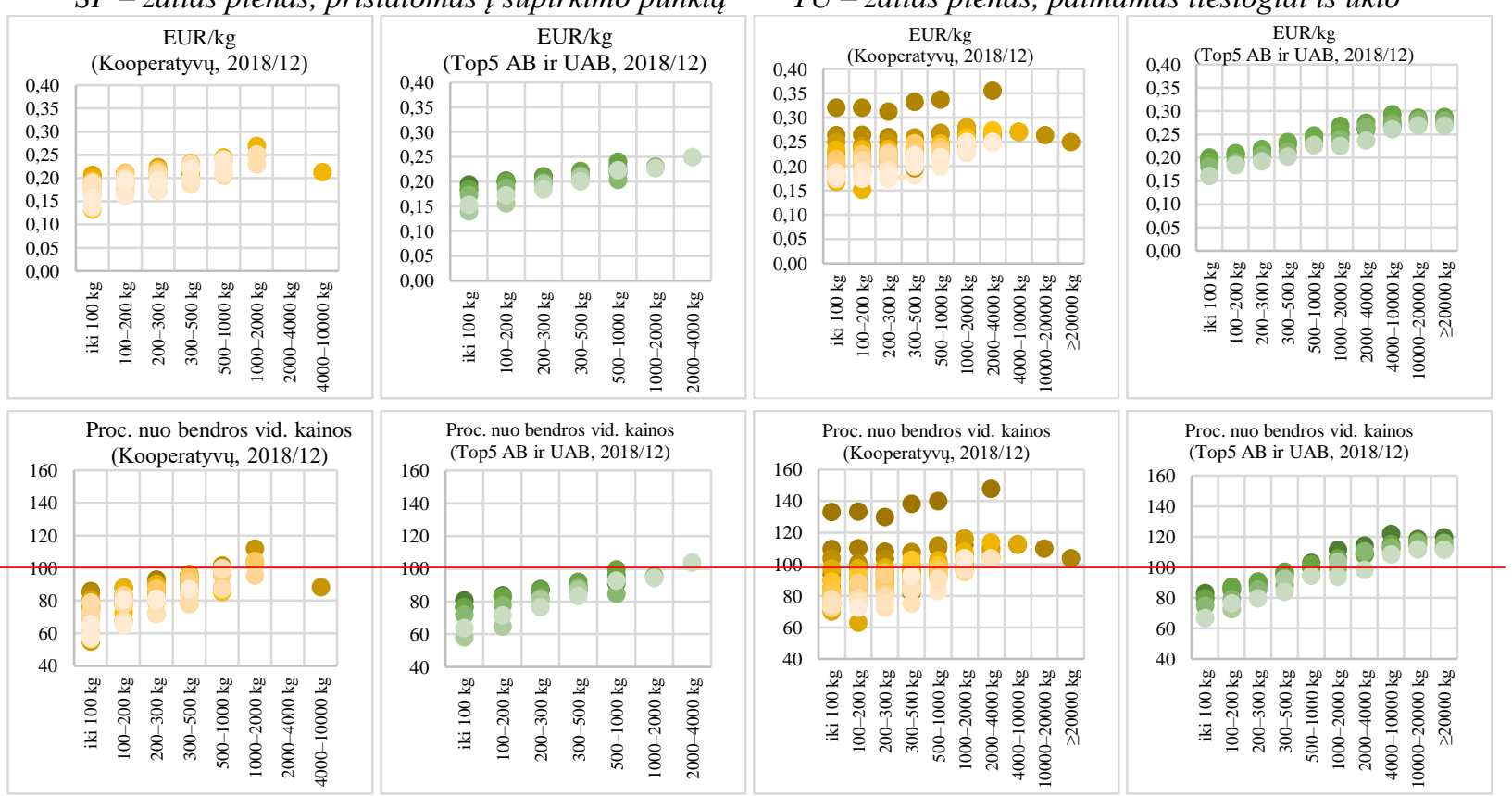

4 pav. Kooperatyvų ir penkių didžiausių pieno perdirbimo įmonių mokamos žalio pieno kainos pagal per vieną dieną iš gamintojo superkamo pieno kiekị

Pastaba: Top5 perdirbejjai: $A B$ „Žemaitijos pienas “, $A B$ „Pieno žvaigždès“, UAB „,Marijampolès pieno konservai“, $A B$ „,Rokiškio sūris" ir AB , Vilkyškiu pienine“"; i tyrima itrauktu 27 kooperatyvu 2018 m. liepos mèn. ir 30 kooperatyvu 2018 m. gruodžio mèn. mokamos pieno kainos. „EKO Žemaitija“ ir „,EKO tikslas “ iš kitu kooperatyvu išsiskiria aukšta pieno kaina, nes piena superka vien iš ekologiniu ükiu.

Šaltinis: parengta autoriu pagal ŽŪIKVC PAIS skelbima informacija apie žalio pieno pirkèju pateikta vidutine faktine (su priedais ir nuoskaitomis) baziniu rodikliu pieno kainq superkant piena iš pieno gamintoju (EUR/kg). 
Reikia pridurti, kad 2016 m. žalią pieną perdirbimui per kooperatines bendroves (kooperatyvus) pardavė daugiau kaip 8 tūkst. ūkių, kas sudarè 28,1 proc. nuo visų pieną perdirbimui tiekusių ūkių. 27 individualiai veikiantys (neasocijuoti) kooperatyvai iš jų supirko 370,7 tūkst. $t$ žalio pieno ir tai sudare 26,3 proc. vidaus rinkos (Vitunskiene, 2019). Palyginimui galima pridurti, kad kooperatyvų dalis visoje Europos Sajungos žalio pieno rinkoje sudaro apie 55 proc. (Müller, Hanisch, Malvido, Rommel, Sagebiel , 2018), o JAV penkiasdešimt ūkininkams priklausančių geriausių pieno kooperatyvų - beveik 80 proc. šalies žalio pieno rinkos (Cavalheiro, Vieira, Costa, 2015).

LR konkurencijos tarybos ataskaitoje apie pieno ir pieno produktu sektoriaus rinkos Lietuvoje tyrimą (2015) nurodyta, kad didelè dalis veikiančių kooperatyvų nèra „tikrieji“ - vien savo narių tiekiamu pienu paremti - kooperatyvai, o jų veikla labiau panaši i tarpininkų veiklą. Tyrimo duomenimis, dalis kooperatyvų turi 5 ar mažiau narių, iš kurių superkama itin mažai žalio pieno, taip pat yra ir pieno negaminančių narių, o didžiają dali pieno jie superka iš kitų gamintojų. „Netikros“ kooperacijos, kaip iškraipančios pačią kooperacijos idèją, problemą Lietuvos pienininkystėje akcentuoja ir Lietuvos vidutinių pieno ūkių asociacijos atstovè.

Tokių kooperatyvų praktika sukelia pieno gamintojams abejonę, ar įsitraukimas į kooperatyvo veiklą jiems atneš naudos dèl susiformavusios nuomonès, jog parduodami pieną per kooperatyvą jie praras kainos dali, kuri skirta kooperatyvui išlaikyti (Vituskienė, Droždz, Lauraitienė, Bendoraitytè, 2020). Kita vertus, ị tokių „netikrų“ kooperatyvų (kaip ir kitų pieno supirkimu-perpardavimu užsiimančių įmonių) veiklą Lietuvos žalio pieno rinkoje galima žvelgti ir kitokiu požiūriu - jie, kaip ir tikrieji kooperatyvai, užima dalị rinkos, dèl to mažeja pirkèjų koncentracija rinkoje ir stiprèja konkurencija. Nustatyta, kad per pastarajj vidutinès trukmès laikotarpi žalio pieno vidaus rinkoje pirkẻjų koncentracija lètai mąžta pagal visų pirkejjų individualius duomenis apskaičiuotas Herfindalio-Hiršmano indeksas sumažejo nuo 1104 - 2010 m. iki 1018 - 2018 m. (Vitunskienè, 2019).

4 paveiksle pateikti duomenys rodo, kad tiek vasaros, tiek žiemos sezonu kooperatyvai, kaip ir didžiausios pieno pramonès įmonès, pieno kainą diferencijuoja pagal iš gamintojo superkamo pieno kiekị per dieną - pastarajam didejjant, kaina didejja dèl masto ekonomijos. Kainos dydis taip pat skiriasi ir dèl pieno pristatymo būdo, t. y. kai žalias pienas pristatomas ị supirkimo punktą (4 pav. grafikai kairèje pusèje) ir paimamas tiesiogiai iš ūkio (4 pav. grafikai dešinèje pusèje).

\section{1 lentelè. Žalią pieną superkančių kooperatyvų, mokẻjusių didesnę bazinių rodiklių pieno kainą nei pieno perdirbimo įmonès, dalis $2018 \mathrm{~m}$.}

\begin{tabular}{|c|c|c|c|c|c|c|}
\hline \multirow{2}{*}{ Kooperatyvai mokèjo: } & \multicolumn{3}{|c|}{$\begin{array}{c}\text { SP - žalias pienas, pristatomas ị supir- } \\
\text { kimo punktą }\end{array}$} & \multicolumn{3}{|c|}{$\begin{array}{c}\text { TŨ - žalias pienas, paimamas tiesiogiai } \\
\text { iš úkio }\end{array}$} \\
\hline & $\begin{array}{l}\text { iki } 100 \mathrm{~kg} \\
\text { per dieną }\end{array}$ & $\begin{array}{c}100-200 \mathrm{~kg} \\
\text { per dieną }\end{array}$ & $\begin{array}{c}200-300 \mathrm{~kg} \\
\text { per dieną }\end{array}$ & $\begin{array}{l}\text { iki } 100 \mathrm{~kg} \\
\text { per dieną }\end{array}$ & $\begin{array}{c}100-200 \mathrm{~kg} \\
\text { per dieną }\end{array}$ & $\begin{array}{c}200-300 \mathrm{~kg} \\
\text { per dieną }\end{array}$ \\
\hline \multicolumn{7}{|c|}{ Vasaros sezono metu (2018 m. liepos mèn.) } \\
\hline $\begin{array}{l}\text { Didesnę kainą nei minimali Top5 AB ir } \\
\text { ŪAB kaina }\end{array}$ & $74,1 \%$ & $74,1 \%$ & $74,1 \%$ & $74,1 \%$ & $74,1 \%$ & $74,1 \%$ \\
\hline $\begin{array}{l}\text { Didesnę kainą nei maksimali Top5 AB } \\
\text { ir ŪAB kaina }\end{array}$ & $11,1 \%$ & $14,8 \%$ & $18,5 \%$ & $11,1 \%$ & $14,8 \%$ & $18,5 \%$ \\
\hline \multicolumn{7}{|c|}{ Žiemos sezonu metu (2018 m. gruodžio mèn.) } \\
\hline $\begin{array}{l}\text { Didesnę kainą nei minimali Top5 AB ir } \\
\text { ŪAB kaina }\end{array}$ & $70,0 \%$ & $70,0 \%$ & $56,7 \%$ & $70,0 \%$ & $66,7 \%$ & $66,7 \%$ \\
\hline $\begin{array}{l}\text { Didesnę kainą nei maksimali Top5 AB } \\
\text { ir ŪAB kaina }\end{array}$ & $6,7 \%$ & $6,7 \%$ & $20,0 \%$ & $30,0 \%$ & $13,3 \%$ & $33,3 \%$ \\
\hline
\end{tabular}

Pastaba: žalio pieno kainos lygis (proc.) apskaičiuotas kiekvieno supirkèjo mokamas kainas palyginus su vidutine visų supirkèjų mokama kaina; Top5 perdirbèjai: AB „Žemaitijos pienas“, AB „Pieno žvaigždès“, UAB „Marijampolès pieno konservai“, AB „Rokiškio sūris“ ir AB „Vilkyškių pieninė“; i tyrimą ịtrauktų 27 kooperatyvų $2018 \mathrm{~m}$. liepos mèn. ir 30 kooperatyvų $2018 \mathrm{~m}$. gruodžio mèn. mokamos pieno kainos. „EKO Žemaitija“ ir „EKO tikslas“ iš kitų kooperatyvų išsiskiria aukšta pieno kaina, nes pieną superka vien iš ekologinių ūkių.

Šaltinis: apskaičiuota autorių pagal ŽŪIKVC PAIS skelbiamą informaciją apie žalio pieno pirkèjų pateiktą vidutinę faktinę (su priedais ir nuoskaitomis) bazinių rodiklių pieno kainą superkant pieną iš pieno gamintojų (EUR/kg)

Palyginus kooperatyvų ir pieno pramonès įmonių mokamas kainas už bazinių rodiklių žalią pieną bei jų lygị, apskaičiuotą nuo vidutinès visų supirkėjų mokamos kainos, matyti, kad pagal superkamo pieno kiekio grupes (pvz., iki 100 kg, 100-200 kg, 200-300 kg per dieną) (1 lentelè): 
- didelè dalis kooperatyvų tiek vasaros (74 proc.), tiek žiemos (57-70 proc.) sezonu mažiems pieno gamintojams mokèjo didesnę kainą nei už atitinkamą pieno kiekį buvo mokèta penkių didžiausių perdirbimo įmonių (Top5) minimali kaina;

- daugiau nei Top5 perdirbejjų mokèta maksimali kaina už atitinkamą pieno kiekį mokèjo 11-19 proc. kooperatyvų vasaros sezonu ir 7-33 proc. kooperatyvų žiemos sezonu.

\section{Išvados ir diskusija}

Nors kooperatyvai vadovaujasi principais ir praktika, kurie labai skiriasi nuo standartinès ekonomikos teorijos (Ménard, 2017), tačiau jie vis tiek gali būti efektyvūs, stabilūs bei klestintys (Kispál-Vitai, Regnard, Kövesi, Guillotte, 2019) ir yra reikšmingi šiuolaikinèse moderniose žemès ūkio ir maisto produktų rinkose, kuriose mainus valdo stabilūs sutartiniai santykiai (Crespi, Saitone, Sexton, 2012). Vakarų autoriai ieško priežasčių, kodėl ir XXI a. gamintojai renkasi būtent klasikiniais bendradarbiavimo principais grindžiamą kooperatinę struktūrą (Kispál-Vitai, Regnard, Kövesi, Guillotte, 2019), o mes, Lietuvos tyrejjai, vis dar labai ribotai suprantame, kodèl šalies žemès ūkio gamintojai (ypač maži) neịsitraukia ị tokias struktūras. Mūsų tyrimas atskleidè, kad tik kas dvidešimt ketvirtas mažas ūkis savo pagamintus maisto ir žemės ūkio produktus parduoda per kooperatyvus, o kas dvidešimt aštuntam kooperatyvas užtikrina didesnes gamintojo kainas.

Konkurencinio kriterijaus teorija paaiškina, kad oligopsoninėse rinkose kooperatyvai užtikrina didesnes žemès ūkio produktų kainas regiono rinkoje, o naujausi empiriniai įrodymai patvirtina šiuos teiginius žaliavinių žemès ūkio produktų rinkoje. Mūsų tyrimo rezultatai parodè, kad didelè dalis žalią pieną superkančių kooperatyvų mažiems pieno gamintojams moka didesnę kainą nei penkių didžiausių pieno perdirbimo akcinių bendrovių nustatyta minimali kainą, o apie penktadalis kooperatyvų (žiemos sezonu) ir apie trečdalis kooperatyvų (vasaros sezonu) moka didesnę kainą nei tų pačių akcinių bendroviu nustatyta maksimali kaina. Müller, Hanisch, Malvido, Rommel, Sagebiel, (2018) taip pat nustaté, kad didesnè kooperatyvu rinkos dalis daro teigiamą poveiki kainų lygiui ir stabilumui Europos pieno rinkose, kai kontroliuojamas keletas kitu rinkos charakteristiku. Grashuis (2020) nustatè, kad grūdu rinkodaros kooperatyvai paskatina konkurentus reikšmingai padidinti kukurūzų kainą. Tad politikos formuotojai turètų atsižvelgti ị tai, kad kooperatyvų skatinimas gali teigiamai paveikti žemės ūkio produktų kainas ir jų stabilumą, ypač oligopsoninèse rinkose, kuriose vyrauja keli dideli pirkëjai.

\section{Literatūros sąrašas}

Agarwal, B., Dorin, B. (2019). Group farming in France: Why do some regions have more cooperative ventures than others? // Environment and Planning A: Economy and Space, 51(3), 781-804.

Atkočiūnienė, V., Aleksandravičius, A., Dautartė, A., Vitunskienė, V., Zemeckis, R. (2017). Ūkių modernizacija rinkų ir kaimo vystymosi kontekste: Lietuvos atvejis. Aleksandro Stulginskio universitetas. Akademija.

Cavalheiro, E. A., Vieira, K. M., Costa, C. (2015) Market concentration in US milk processors and his influence at price paid to cow milk producers // Corporate Ownership \& Control, 13(1): 627-634.

Crespi, J. M., Saitone, T. L., Sexton, R. J. (2012). Competition in US farm product markets: do long-run incentives trump short-run market power? // Applied Economic Perspectives and Policy, 34(4), 669-695.

Grashuis, J. (2020). The Competitive Impact of Cooperatives on the Spot Market: A Spatial Analysis of Iowa Corn Prices // Journal of Agricultural \& Food Industrial Organization, 1(ahead-of-print).

Herbel, D., Ourabah Haddad, N. 2012. Successful farmer collective action to integrate food production into value chains // Food Chain, 2(2), 164-182.

Hoffman, S., Royer, J. S. (1997). Evaluating the competitive yardstick effect of cooperatives on imperfect markets: A simulation analysis, 1839-2016-152198.

Kieselienè, S. (2019). Ištyrè, kas vyksta su kooperatyvais. Delfi: Agroverslo naujienos. https://www.delfi.lt/agro/agroverslo-naujienos/istyre-kas-vyksta-su-kooperatyvais.d?id=80862147 [10 04 2019].

Kispál-Vitai, Z., Regnard, Y., Kövesi, K., Guillotte, C. A. (2019). Cooperative case studies from three countries: Is membership a problem or a solution in the 21st century? // Society and Economy, 41(4), 467-485.

Kuliešis, G., Pareigienè, L. 2010. Nuostatų kooperuotis vertinimas // Vadybos mokslas ir studijos-kaimo verslu ir jų infrastruktūros plètrai, (5), 108-115.

LR Konkurencijos taryba (2015). Lietuvos Respublikos konkurencijos tarybos pranešimas apie atliktą pieno ir pieno produktų sektoriaus rinkos tyrimą. Bylos Nr. 14//1/1/08/33/077. 2015-06-21, Nr. 5S-14/2015, Vilnius.

Lutz, J., Smetschka, B., Grima, N. (2017). Farmer Cooperation as a Means for Creating Local Food SystemsPotentials and Challenges // Sustainability, 9(6), 925. 
Melnikienė, R., Vidickienè, D. (2019). Evaluation of the Lithuanian Agricultural Policy Based on the Analysis of Qualitative Structure // Public Policy and Administration, 18(1), 52-67.

Ménard, C. (2018). Organization and governance in the agrifood sector: How can we capture their variety?.// Agribusiness, 34(1), 142-160.

Myers, R. J., Sexton, R. J., Tomek, W. G. (2010). A century of research on agricultural markets // American Journal of Agricultural Economics, 92(2), 376-403.

Müller, M., Hanisch, M., Malvido, A., Rommel, J., Sagebiel, J. (2018). The structural effect of cooperatives on price volatility in the European dairy sector. Applied Economics Letters, 25(8), 576-579. 18-46.

Ortmann, G. F., King, R. P. (2007). Agricultural cooperatives I: History, theory and problems // Agrekon, 46(1),

Pareigienè, L., Ribašauskienė, E. (2008). Kooperacijos plètros vertinimas // Vadybos mokslas ir studijos-kaimo verslu ir ju infrastruktūros plètrai, (1), 127-133.

Souza, A. B. D., Fornazier, A., Delgrossi, M. E. (2020). Local food systems: potential for new market connections for family farming // Ambiente \& Sociedade, 23.

Torgerson, R. E., Reynolds, B. J., Gray, T. W. (1998). Evolution of cooperative thought, theory, and purpose // Journal of Cooperatives, 13(1142-2016-92691), 1-20.

Treinys M. (1990). Talkos galia: žemès ūkio kooperacija vakar ir šiandien. - Vilnius: Mintis.

Vitunskienè, V. (2001). Lietuvos žemès ūkio restruktūrizacijos politikos įtaka žemès ūkio subjektų konkurencingumui // Vagos, 50(3), 75-84.

Vitunskienè, V. (2019). Žalio pieno vidaus rinkos struktūra ir koncentracija Lietuvoje // Management theory and studies for rural business and infrastructure development, 41(4), 576-588.

Vitunskienè, V., Droždz , J., Bendoraitytè, A. (2020). Lietuvos mažų šeimos ūkių darnumo tyrimo kiekybinès apklausos rezultatai. Pagal vykdomą tarptautini projektą FAMFAR "Mažų šeimos ūkių vaidmuo siekiant tvaraus žemės ūkio ir maisto produktų sektoriaus vystymosi Vidurio ir Rytų Europos šalyse” (2019-2021), finansuojamą Lenkijos akademinių mainų nacionalinès agentūros (NAWA). Sutarties NR. PPI/APM/2018/1/00011/U/001

Vituskienė, V., Droždz, J., Lauraitienė, L., Bendoraitytė A. (2020). 2003-2018 m. žemès ūkio politikos priemonių tyrimas (ịvertinimas), siekiant veiksmingesnès žemės ūkio politikos bei smulkių ir vidutinių ūkių ekonominio ir socialinio gyvybingumo. Žemès, maisto ūkio, žuvininkystès ir kaimo plètros mokslinių tyrimų ir eksperimentinės plètros 20152020 metų programos MTTV projekto galutinė ataskaita, Kaunas.

Zakić, N., Vukotić, S., Cvijanović, D. (2014). Organisational models in agriculture with special reference to small farmers // Economics of Agriculture, 61(297-2016-3632), 225-237.

ŽŪM (2020). Žemès ūkio kooperacijos skatinimas: kooperacijos žinių sklaidos modelio sukūrimas. Viešoji konsultacija dèl Žemès ūkio kooperacijos skatinimo: kooperacijos žinių sklaidos modelio sukūrimo. - https://epilietis.lrv.lt/lt/konsultacijos/viesoji-konsultacija-del-zemes-ukio-kooperacijos-skatinimo-kooperacijos-ziniu-sklaidos-modelio-sukurimo [06 02 2020].

\section{Summary}

\section{REPRESENTING THE INTERESTS OF SMALL FARMS IN THE MARKET THROUGH COOPERATIVES: EFFECT ON PRODUCERS' PRICE}

The study addresses the problem of to what extent and in what way the interests of small farms are represented by cooperatives in the market of agricultural products. The empirical analysis aims to determine the extent of small farms' involvement in formal cooperation and the impact of cooperatives on the prices of their products in Lithuania. The analysis is based on the theory of competitive yardstick, where a cooperative can be considered as a regulator of prices in the market. This theory argues that the existence of a cooperative will force the profit-maximizing companies to behave more competitively in an oligopsony market. When a cooperative offers more favourable prices to farmers because of its classic practice of providing services at cost price, profit-maximizing processing companies try to match the price paid by the cooperative in order to not lose raw material suppliers. The data obtained from the survey carried out in small farms reveal that a small part of small farms in Lithuania sell their agricultural and food products to cooperatives and that even a smaller part of those farms is offered a higher price. The analysis of ŽŪIKVC PAIS data on the price paid by buyers per kilogram of raw milk, reveals that most cooperatives pay a higher price for small milk producers than the minimum price set by the five largest milk processing companies in Lithuania. About one-fifth of cooperatives (during the winter season) and up to a third of cooperatives (during the summer season) pay a higher price than the maximum price set by the same joint stock companies.

Keywords: small farms, cooperatives, milk processors, producer price, competitive yardstick.

JEL Codes: L22, Q12, Q13. 